\title{
THE GENESIS OF THE McMURDO ICE SHELF, ANTARCTICA
}

\author{
By Frank Debenham \\ (Herne Lodge, St. Eligius Street, Cambridge, England)
}

\begin{abstract}
The recent discovery (Gow and others, 1965) of a layer of fresh water under the McMurdo Ice Shelf invites a reconsideration of the early theory of its genesis. A general description of the area is given to record the wide area in which marine bottom deposits overlie freshwater ice.

RÉsumÉ. La genèse du McMurdo Ice Shelf. La découverte récente (Gow and others, 1965) d'une strate d'eau douce sous le McMurdo Ice Shelf, invite à reconsidérer la théorie de sa genèse. Une description générale de la zone est donnée pour préciser la large partie où des dépôts marins de fond se trouvent à la surface de glace d'eau douce.
\end{abstract}

Zusammenfassung. Die Entstehung des McMurdo-Ice-Shelf's, Antarktika. Die jüngste Entdeckung (Gow and others, 1965) einer Schicht von Süsswasser unter dem McMurdo Ice Shelf gibt Anlass zu einer Überprüfung der früheren Theorie seiner Entstehung. Eine allgemeine Beschreibung des Gebietes gibt eine Übersicht über den weiten Bereich, in dem Ablagerungen am Meeresgrund Süsswassereis überdecken.

THE floating ice shelf which fills the southern end of McMurdo Sound may well be the strangest ice shelf in the world. To begin with, it has a dual origin in that the western portion is really the sea-level end of a short but steep high-level glacier named after Dr. Koettlitz, the doctor of Scott's Discovery expedition, while the eastern and greater portion of the ice shelf can be taken, at first sight, as a branch of the huge Ross Ice Shelf which has turned almost at right angles around the end of Minna Bluff to push its way between the three well-named islands, White Island, Black Island and Brown Island, mainly between the two latter (Fig. I).

Almost every flight from the American McMurdo Sound air strip passes over part of the ice shelf, but it is still rarely traversed on foot because of the debris-strewn surface of its central part, shown in long lines of moraine, which are evidence for the movement of the ice shelf, probably at a very slow rate. The existence of this moraine shows in itself that there is annual loss from the surface, in direct contrast to the Ross Ice Shelf, where there is a yearly increase of up to a foot $(30 \mathrm{~cm}$.) of compressed snow. It was therefore early suspected that to account for the extent of the moraine-bearing ice, there must be some increase from below to compensate for the loss from above.

To appreciate the curious effect of this loss by thaw, one may reconstruct a traverse over the surface from the American air strip due west across the whole ice shelf to the western mountains. The air strip is on thick sea ice from one to three years of age and therefore 3 to $5 \mathrm{ft}$. ( $\mathrm{I}$ to $\mathrm{I} \cdot 5 \mathrm{~m}$.) above sea-level. After three or four miles ( 5 to $6 \mathrm{~km}$.) the sheet is nearer I $5 \mathrm{ft}$. $(5 \mathrm{~m}$.) thick, still mostly snow like immature or young shelf ice. Then rather suddenly the traveller begins to cross lines of surface moraine and the height above sea-level increases still more until at the worst part of the crossing he may be $50 \mathrm{ft}$. ( $16 \mathrm{~m}$.) above sea-level. The surface is almost impossible for sledges, for not only is the covering of fine silt more and more dense, but one is crossing a myriad of thaw channels, which at the height of summer may be 3 or $4 \mathrm{ft}$. ( $\mathrm{I} \mathrm{m}$.) deep. At the highest part he will cross one or two shear cracks showing that the ice coming from the Koettlitz Glacier is moving at a different rate from that of the eastern half. Once across the most silt-laden portion, the traveller is on a thinner shelf (perhaps ${ }_{1} 5 \mathrm{ft}$. ( $5 \mathrm{~m}$.) above sea-level), but still with fine silt in the ice which induces a tremendous flow of thaw water over the lower few miles of the glacier.

The duration of the thaw is extraordinary, beginning in November and rising to a peak in mid-January. But long after the air temperature has fallen well below freezing point, the flow goes on under thin sheets of ice, right into March when visited by one of the Scott parties. With such extensive thaw in mind, it is no wonder that a recent drilling through the ice shelf 


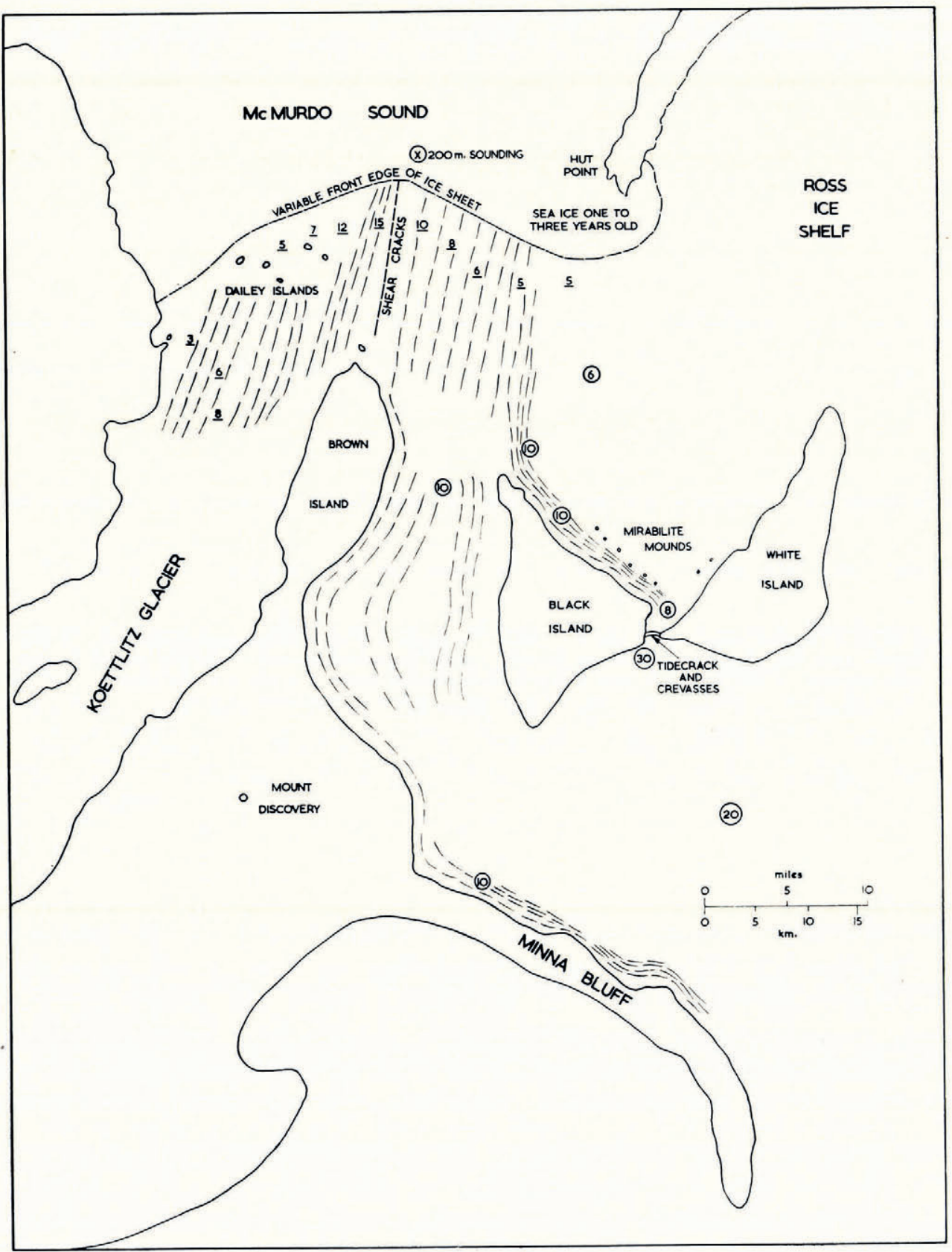

Fig. I. Map of McMurdo Ice Shelf and surrounding areas. Flecking shows the extent of shelly moraine based on observations by the author in I I II (northern part) and reports in diaries of Koettlitz and Bernacchi on sledge journeys made in $1902-03$. Approximate heights of ice surface above sea-level in metres are shown. Figures underlined are from the author's observations, those ringed are deduced from barometric recordings of other sledgers. The ice front is very variable, especially on the Koettlitz Glacier side. The average depth of McMurdo Sound is around 400-500 m. except for one sounding shown on the map 
near its end by an American party (Gow and others, 1965) should find itself passing through nothing but freshwater ice and into a layer of fresh water lying above the sea-water, colder and heavier, below.

The real mystery of the McMurdo Ice Shelf begins to show itself when we examine the materials of the moraine and silt on the surface. Almost everywhere there is silt there is liable to be some of the fine hair-like pieces of sponge spicules scattered by the wind. In several special places these sponges, whose proper habitat is at depths of about 60 to roo m., have been found, together with other sea-floor invertebrates, on patches of marine mud in the position of growth. In association with these recent forms of life there are even more peculiar deposits of a mineral known as mirabilite, a very pure form of sodium sulphate or Glauber's salt, clearly derived from sea-water. In addition to these things a complication has arisen in the form of corpses, often headless, of a very large bottom-dwelling fish, found on the surface of the ice shelf. Since they could have swum up the thaw streams, the fish cannot be regarded as equivalent to the sea-bottom animals or the deposits of mirabilite.

Naturally these curious phenomena have given rise to various theories by which to explain them, and having been responsible for the earliest paper on the subject (Debenham, 1920) perhaps I may be permitted to amend some of the early conclusions. We may begin with an apology for none of us recognizing the now obvious connection between the densest moraine cover and heaviest thaw region coinciding with the thickest part of the shelf, a connection which is now confirmed by the recent discovery of a freshwater layer under the ice for at least part of the year. It has helped in disposing of one difficulty I had when introducing the idea of bottom material being frozen in at the base of the ice shelf. The theory was perhaps permissible when considering individual shells and sponges, but it did not suit the two wellknown cases of quite large sheets of bottom material extending over at least 20 square yards ( 7 square metres), one discovered by Professor David on the Nansen Ice Shelf in 1909, and the other by Griffith Taylor in I9I I, a full description of which is given in Debenham (1920). Such wholesale freezing of marine mud to a shelf moving however slowly overhead needed something like a quick freeze, a matter of days rather than weeks as would be required by frazil ice forming round the objects from sea-water. The case is much simplified if we imagine a hole in the shelf pouring in fresh water at just above the freezing point and surrounding a patch of mud at something like three degrees below the freezing point of fresh water. Those patches of bottom material have got to be accounted for, and the problem has at least become easier!

Now we may turn to the wider aspects and the probable state of affairs much farther back at the beginning of the McMurdo Ice Shelf between the eastern end of Minna Bluff and White Island. Here it is definitely an offshoot of the main Ross Ice Shelf, though it has to make a turn through nearly a right angle from its previous direction of movement. This it does with many crevasses and much slowing down of the motion as well as undulations or waves in the surface.

The northern portion of this offshoot seeks to pass between White Island and Black Island, where it is restricted both by the narrowness of that strait, and the fact that there is a rock bar under the shelf, over which the ice has to rise up about $50 \mathrm{ft}$. ( $16 \mathrm{~m}$.) and then descend about $\mathrm{r} 4 \mathrm{o} \mathrm{ft}$. ( $43 \mathrm{~m}$.), these figures being estimates by Captain Scott on his journey in $\mathrm{I} 902$. This restriction obviously slows down the rate of movement towards the north, and it is here that we find silt showing along the coast of Black Island with occurrences of raised marine muds and patches of mirabilite in the mounds described by Ferrar and others (see Fig. I). There is also the association of maximum silt with maximum thaw and maximum thickness of the shelf, already noted much farther north.

Turning now to the southern portion of the offshoot, we find less restriction to its movement between Black Island and Brown Island, which incidentally is completely covered with ice-borne silt and animal remains, and dissected by deep thaw streams. It seems that silt on 
the surface of the ice appears soon after the shelf has made its right-angled turn around the end of Minna Bluff. One suspects that this early appearance of silt is due mainly to its being blown off the bare land surface of the bluff, and consequently leading to the thaw streams beginning, and a thickening of the ice shelf as one gets near the land. It must be somewhere along this stretch that the animal remains begin to appear on the surface, but I have no information as to where. Recent maps seem to indicate that this silt-laden "moraine" follows the coast line closely up to Brown Island, where, as noted by Dr. Koettlitz in 1902, the moraine fills the strait and the summer thaw produces temporary rivers up to $3 \mathrm{ft}$. (1 $\mathrm{m}$.) deep, much of which must find its way down holes and shear cracks to the sea-water.

Though the rate of movement of the ice shelf must be very slow, some of the shear cracks should be wide enough during January to permit sounding to find out the depth and temperature of the freshwater layer without any drilling. If these deductions from the discovery of large amounts of fresh water under the ice shelf are verified by further field work, we may expect to find that the major part of the McMurdo Ice Shelf has a quite different origin from the Ross Ice Shelf and must be regarded as freshwater ice derived as indicated above from its own thaw water.

The original theories are still suspect, of course, though finding support from what should have been deduced long ago. The provenance of the deposits of mirabilite is still a matter of conjecture, and altogether a great deal of further research on this curious ice shelf is urgently called for.

In this paper some use has been made of the manuscript sledge diaries of Scott, Koettlitz, Bernacchi and Hodgson which are in the possession of the Scott Polar Research Institute, Cambridge, England.

MS. received 2 March 1965

\section{REFERENCES}

Debenham, F. 1920. A new mode of transportation by ice: the raised marine muds of south Victoria Land. Quarterly Fournal of the Geological Society of London, Vol. 75, Pt. 2, p. 51-76.

Gow, A. J., and others. I 965 . New light on the mode of uplift of the fish and fossiliferous moraines of the McMurdo Ice Shelf, Antarctica, by A. J. Gow, W. F. Weeks, G. Hendrickson and R. Rowland. Journal of Glaciology, Vol. 5, No. 42, p. $813^{-28}$. 